
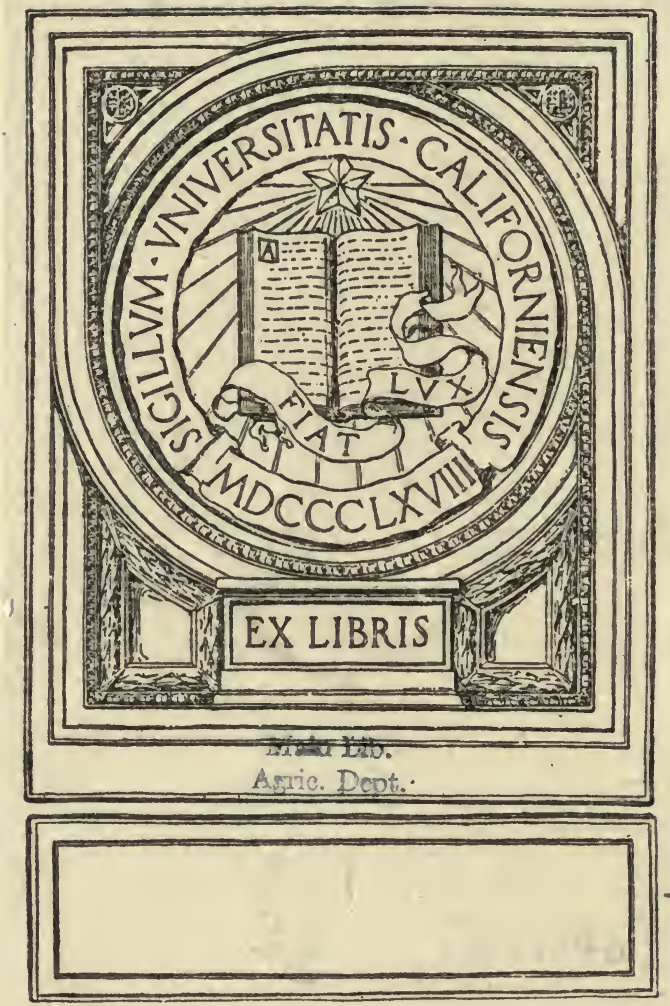
Digitized by the Internet Archive in 2007 with funding from Microsoft Corporation 

BUREAU OF CHEMISTRY.-Circulan No. 22.

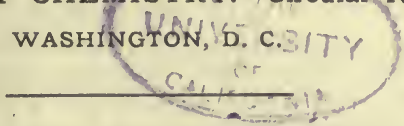

COOPERATIVE WORK ON THE TITER TEST, ASSOCIATION OF OFFI. CIAL AGRICULTURAL CHEMISTS, 1904.

\section{METHODS INVESTIGATED.}

This important test has been a subject of study in the association for two years. The various modifications of the test in use in this country did not give concordant results, and several of the largest business houses using it expressed a desire that this association should cooperate with them, as had been done in the case of the tannin industry, in the preparation of a satisfactory and uniform method. As a preliminary step, samples of fats were sent out to nineteen chemists to find out what methods were in use and how the results obtained by the various modifications would agree. The following directions were sent with the samples of fat:

State the details of the method employer, size and thickness of test tube used, and capacity of bottle.

Give saponification value of the fatty acids.

State the temperature of the room at time of test and the kind and dimensions of thermometer used, especially the size of the bulb. If possible, have the thermometer checked against a standard.

It was found that modifications of two methods were in general use in this country, but that the details of the methods as carried out in the different laboratories were varied and could only lead to diversity of results. It was also found that no definite style of thermometer was used, dimensions of the bulbs rarying greatly, some being quickacting and some slow-acting thermometers. This fact also is bound to affect the results. These two methods gave quite different figures, and no very close agreement was obtained by analysts using the same method. Evidently a uniform method and a uniform thermometer were essential, and it was decided to try for further work two methods which represented the two types in use, namely, the Dalican method, as used by James Boyce, American Cotton Oil Company, and the Wolfbauer method, as used by A. G. Manns, of Armour \& Co.

\section{Dalican Method.}

APPARATÚs.

A round iron or metallic dish, 1.5 liters capacity.

A porcelain dish, 2 liters capacity.

Test tube, $22 \mathrm{~mm}$ to $25 \mathrm{~mm}$ diameter, $15 \mathrm{~cm}$ long, the walls of the tube to be 1.5 mm thick.

One bottle, $7.5 \mathrm{~cm}$ diameter, $15 \mathrm{~cm}$ deep, to have wide mouth, with cork of sufficient size to hold test tube. Bottle to be of clear glass, with thick wall.

A delicate certified thermometer, reading in $\frac{1}{10}$ degrees, graduated from $0^{\circ}$ to $70^{\circ} \mathrm{C}$, bulb of thermometer to be not more than $6 \mathrm{~mm}$ in diameter and $3.4 \mathrm{~cm}$ long.

An accurate thermometer to hang alongside of the apparatus to record the temperature of the room in which test is chade. 


\section{OPERATION.}

Weigh 50 grams of the fat into a metal dish. Measure $40 \mathrm{cc}$ of caustic soda, $36^{\circ}$ Baumé, and $50 \mathrm{cc}$ of 95 per cent alcohol into the small bottle. Heat the fat over a gentle flame to $115^{\circ}$ to $120^{\circ} \mathrm{C}$. Shake the alcohol and soda solution well together and add to the fat. Stir vigorously over a gentle fire until soap becomes sufficiently dry to form pieces which will no longer adhere to the spatula by gentle pressure.

Redissolve in $20 \mathrm{cc}$ of alcohol and again dry to a condition in which the soap will not adhere to the spatula by pressure.

Transfer the dry soap to the porcelain dish. Add 1 or 2 liters of boiling water and keep the mixture boiling for 40 minutes. Replace, by adding cold water, about the same quantity of water which has been evaporated by the previous boiling. Add to the soap solution $70 \mathrm{cc}$ of $25^{\circ}$ Baumé sulphuric acid. Boil again until the fatty acids, which will float on top, are perfectly clear and transparent and show no signs of any particle of soap which has not dissolved. Siphon off the acid water and transfer the fatty acids to a small beaker, melt the acids, and allow the water to settle; transfer to a dry beaker and dry in a water bath or on a steam bath for 20 minutes and filter the fatty acids through white filter paper, using a hot-water funnel.

Place the clear fatty acids in the titer tube, filling it two-thirds full, the tube being first warmed in the water bath. Insert the tube in the perforated cork of the large bottle, to serve as an air bath, and hang the delicate thermometer so that the bulb will be exactly in the middle, in all directions, of the mass and allow the fatty acids to cool until the mercury stops falling and just begins to rise agxin. Then move the thermometer rapidly around the sides of the tube, three times to the right and three times to the left, without any up or down motion, finally replacing the thermometer in the center of the tube.

Watch the thermometer as the mercury rises and take the highest point reached as the titer test, at the same time recording the temperature of the room in which the test was made.

\section{Wolfbauer Method.}

Seventy-five grams of the fat are placed in an iron dish with $150 \mathrm{cc}$ of caustic soda lye of 13 per cent to 14 per cent strength. The mixture is boiled to dryness, with constant stirring, so as to avoid scorching. In practice, a 3-pound lard pail is used, instead of the iron dish, and a heavy stirring rod to break up the lumps. The dry granular soap is then transferred to a porcelain dish of about 1,000 ce capacity in which $500 \mathrm{cc}$ of water and $250 \mathrm{cc}$ of sulphuric acid of 60 per cent strength have been previously mixed. The whole is boiled until the soap is decomposed, water being added from time to time to maintain the original volume. An enameled cover is kept on the dish while boiling. When the fatty acids are perfectly transparent they are washed several times with boiling hot water, allowed to settle, decanted, filtered through several thicknesses of dry filter paper, and dried for four hours at $105^{\circ} \mathrm{C}$. The fatty acids when dried are cooled to about $15^{\circ}$ or $20^{\circ} \mathrm{C}$. above the expected titer and transferred to a special tube 1 inch in diameter and 4 inches in length. The tube is made of glass about $\frac{3}{67}$ of an inch thick. It is placed in a bottle fitted with a cork, which is perforated so as to hold the tube rigidly when in position. The thermometer, graduated to $0.1^{\circ} \mathrm{C}$., is suspended so that it can be used as a stirrer, and the mass is stirred slowly until the mercury remains stationary for at least 30 seconds. The thermometer is then allowed to hang quietly, with the bulb in the center of the mass, and the rise of the mercury is observed. The highest point to which it rises is taken as the titer of the fatty. acids.

The fatty acids should always be tested for complete saponification, as follows:

About 3 cc of the fatty acids are placed in a test tube and about $15 \mathrm{cc}$ of strong alcohol added, the mixture brought to a boil, and an equal volume of ammonia (sp. gr. 0.96) is added. A clear solution should result, turbidity indicating presence of unsaponified fat. $a$

It will be noted that the method differs from the Dalican test in two important details. First, the fatty acids are thoroughly dried; second, the method gives a definite time at which to stop stirring. The thorough drying of the fatty acids was adopted as given above, as it has been clearly demonstrated that moisture in the fatty acids lowers the titer about $0.4^{\circ}$ to $0.5^{\circ} \mathrm{C}$. Further, if the fatty acids are dried in hydrogen gas by heating up to $150^{\circ} \mathrm{C}$., the titer is the same as if the heating was performed in the open air, or as if they were dried in a bath for four hours at $105^{\circ} \mathrm{C} . b$

$a$ Lewkowitsch, Chemical Analysis of Oils, Fats and Waxes, 2d ed., p. 100.

b Ibid., Wolfbauer's work, pp. 134-135. 
Four samples of fat--oleo tearin, edible tallow, yellow grease, and cottonseed oil-were sent to the various chemists desiring to cooperate, with a circular on the methods requesting that the titer of the fatty acids prepared by the different methods of saponification be taken by both methods of stirring and that the thermometer readings for stem exposure be corrected by the following formula:

$\mathrm{T}=\mathrm{T}^{\prime}+\mathrm{u}\left(\mathrm{T}^{\prime}-\mathrm{t}\right) .000154$.

$\mathrm{T}^{\prime}=$ observed temperature.

$\mathrm{u}=$ length of mercury column above the fat in degree divisions of the thermometer.

$\mathrm{t}=$ room temperature.

\section{COOPERATIVE WORK.}

The reports of twenty-five chemists on the four samples of fat are collected in Tables I and II.

TABLE I.-Results of cooperative work on the titer test for 1904-Wolfbauer method of stirring.

Analyst.

F. C. Weber, U. S. Department of Agricul-

A. H. Schmidt, Schwarzsehild \& Sulzberger,

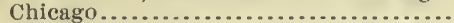

L. M. Tolman, U. S. Department of Agriculture...................................... David Wesson, Southern Cotton Oil Com-

A. G. Manns, Armour \& Co., Chicago........

W. E. Tinney, Armour \& Co., South Omaha,

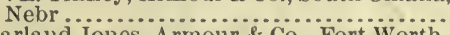
Garland Jones, Armour \& Co., Fort Worth,

c. F. Hagedorn, A A........................ Stock Yards, Ill ........................

A. V. H. Mory, Armour Packing Company,

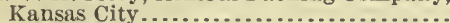
James Boyce, American Cotton Oil Company, Chicago (1) .........................

James Boyce, American Cotton Oil Com-

James Boyce, American Cotton Oil Company, Chicago (3) ...................... James Eoyce, American Cotton Oil Company, Chicago (4) ........................... R. D. Oilar, Wilcox Lard Company, New J. E. Weber, Procter \& Gamble, Cincinnati,

M. H. Ittner, Colgate \& Co., New York...... Wilson Low, Cudahy Packing Company,

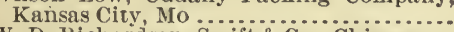

W. D. Richardson, Swift \& Co., Chicago....

E. K. Nelson, Nelson Morris \& Co., Chicago.

A. H. Gill, Massachusetts Institute of Technology, Boston.

A. G. Stillwell, Stiliwell Provisioner Laboratory, New York

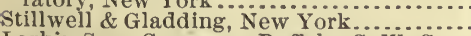
Larkin Soap Company, Buffalo, C. W. C... Larkin Soap Company, Buffalo, w. W. S... Larkin Soap Company, Buffalo, J. C. T....

Minimum

Difference

\begin{tabular}{|c|c|c|c|c|c|c|c|}
\hline & Oleos & tearin. & & & Edible & 2 & \\
\hline $\begin{array}{l}\text { Wolf- } \\
\text { bauer } \\
\text { fatty } \\
\text { acids. }\end{array}$ & $\begin{array}{l}\text { Room } \\
\text { tem- } \\
\text { pera- } \\
\text { ture. }\end{array}$ & $\begin{array}{l}\text { Dali- } \\
\text { can } \\
\text { fatty } \\
\text { acids. }\end{array}$ & $\begin{array}{l}\text { Room } \\
\text { tem- } \\
\text { pera- } \\
\text { ture. }\end{array}$ & $\begin{array}{l}\text { Wolf- } \\
\text { bauer } \\
\text { fatty } \\
\text { acids. }\end{array}$ & $\begin{array}{l}\text { Room } \\
\text { tem- } \\
\text { pera- } \\
\text { ture. }\end{array}$ & $\begin{array}{l}\text { Dal:- } \\
\text { can } \\
\text { fatty } \\
\text { acids. }\end{array}$ & $\begin{array}{l}\text { Room } \\
\text { tem- } \\
\text { pera- } \\
\text { ture. }\end{array}$ \\
\hline${ }^{\circ} C$. & ${ }^{\circ} C$. & ${ }^{\circ} C$. & ${ }^{\circ} C$. & ${ }^{\circ} \mathrm{C}$. & ${ }^{\circ} C$. & ${ }^{\circ} C$ & ${ }^{\circ} C$. \\
\hline 50.55 & 24 & 50.6 & 23 & 42.2 & 25 & 42.35 & 23 \\
\hline 50.60 & 24 & 50.6 & 16 & 42.3 & 24 & 42.40 & 16 \\
\hline 50.70 & 23 & 50.67 & 18 & 42.3 & 23 & 42.30 & 28 \\
\hline $\begin{array}{l}50.88 \\
50.91\end{array}$ & 25 & $\begin{array}{r}50.94 \\
\ldots .\end{array}$ & 26 & $\begin{array}{l}42.46 \\
42.55\end{array}$ & $\begin{array}{c}27 \\
\cdots\end{array}$ & $\begin{array}{r}42.43 \\
\ldots . . . .\end{array}$ & 26 \\
\hline 50.40 & 25 & 50.3 & 25 & 42.45 & 27 & 42.45 & 25 \\
\hline 50.5 & 37 & 10 & $\cdots$ & 42.50 & 31 & & \\
\hline 50.4 & 28 & 50.26 & 28 & 41.71 & 28 & 42.19 & 28 \\
\hline $\begin{array}{l}50.4 \\
50.4\end{array}$ & 25 & 50.80 & 26 & $\begin{array}{l}42.41 \\
41.80\end{array}$ & 26 & 42.83 & 26 \\
\hline 50.83 & & & & 42.62 & & & \\
\hline 50.78 & & & & 42.44 & & & \\
\hline 50.82 & & & & 42.41 & & & \\
\hline 50.55 & 27 & & & 42.10 & 30.7 & 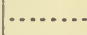 & \\
\hline 50.65 & & 50.30 & & $\begin{array}{l}42.10 \\
42.25\end{array}$ & $\begin{array}{l}24 \\
\ldots \ldots . .\end{array}$ & $\begin{array}{l}42.2 \\
41.85\end{array}$ & 20 \\
\hline & & 50.57 & 22 & & & 42.30 & 23 \\
\hline 50.5 & & & & 42.5 & $\cdots$ & 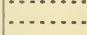 & \\
\hline 50.6 & 30 & & & 42.2 & 30 & & \\
\hline-50.35 & 23 & & & 41.85 & 23 & & \\
\hline $\begin{array}{l}50.85 \\
50.85\end{array}$ & $\cdots$ & ......... & & 42.30 & & 82.2 & \\
\hline 50.85 & 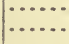 & 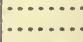 & & $\begin{array}{r}42.00 \\
\ldots \ldots .\end{array}$ & & . & \\
\hline $\begin{array}{r}50.64 \\
50.91 \\
50.35 \\
.56\end{array}$ & ... & $\begin{array}{r}50.50 \\
50.94 \\
50.26 \\
.68\end{array}$ & & $\begin{array}{r}42.26 \\
42.62 \\
41.71 \\
.91\end{array}$ & $\because$ & $\begin{array}{r}42.32 \\
42.83 \\
41.85 \\
.95\end{array}$ & $\mid \begin{array}{l}\cdots \cdots \\
\cdots \cdots \\
\cdots \cdots\end{array}$ \\
\hline
\end{tabular}


TABLE 1.-Results of cooperatice work on the titer test for 1904-Wolfbauer method of stirring-Continued.

Analyst.

F. C. Weber, U. S. Department of Agriculture ........................................... Chicago .............................

L. M. Tolman, U. S. Department of Agriculture............................... pany, New York ...................... A. G. Manns, Armour \& Co., Chicago......... W. E. Tinney, Armour \& Co., South Omaha,

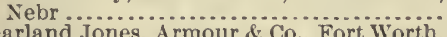
Garland Jones, Armour \& Co., Fort Worth, C. F. Hagedorn, Armour \& Co., National Stock Yards, Ill ......................... A. V. H. Nory, Armour Packing Company, James Boyce, American Cotton Öil Company, Chicago (1) ..........................
ames Boyce, American Cotton Oil Com-

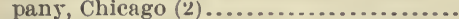

James Boyce, American Cotton Oil Com-

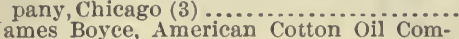
James Boyce, American ${ }^{2}$ pany, Chicago (4)....................

R. D. Oilar, Wilcox Lard Company, New York ........................................

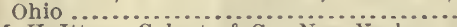

M. H. Ittner, Colgate \& Co., New York.....

Wilson Low, Cudahy Packing Company,

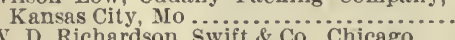

E. K. Nelson, Nelson Morris \& Co., Chicago

A. H. Gill, Massachusetts Institute of Technology, Boston

A. G. Stillwell, stillwell Provisioner Laboratory, New York.

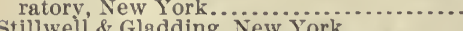

Larkin Soap Company, Buffalo, C. W. C.... Larkin Soap Company, Buffalo, W. W. S....

Larkin Soap Company, Buffalo, J. C. T

Average

Maximum

Yinimum.

Difference

\begin{tabular}{|c|c|c|c|c|c|c|c|}
\hline \multicolumn{4}{|c|}{ Yellow ${ }^{\mathbf{3}}$ grease. } & \multicolumn{4}{|c|}{$\underset{\text { Cotton-seed oil. }}{4}$} \\
\hline $\begin{array}{l}\text { Wolf- } \\
\text { bauer } \\
\text { fatty } \\
\text { acids. }\end{array}$ & $\begin{array}{l}\text { Room } \\
\text { tem- } \\
\text { pera- } \\
\text { ture. }\end{array}$ & $\begin{array}{l}\text { Dali- } \\
\text { can } \\
\text { fatty } \\
\text { acids. }\end{array}$ & $\begin{array}{l}\text { Room } \\
\text { tem- } \\
\text { pera- } \\
\text { ture. }\end{array}$ & $\begin{array}{l}\text { Wolf- } \\
\text { bauer } \\
\text { fatty } \\
\text { acids. }\end{array}$ & $\begin{array}{l}\text { Room } \\
\text { tem- } \\
\text { pera- } \\
\text { ture. }\end{array}$ & $\begin{array}{l}\text { Dali- } \\
\text { can } \\
\text { fatty } \\
\text { acids. }\end{array}$ & $\begin{array}{l}\text { Room } \\
\text { tem- } \\
\text { pera- } \\
\text { ture. }\end{array}$ \\
\hline$\circ C$. & ${ }^{\circ} \mathrm{C}$ & ${ }^{\circ} C$. & ${ }^{\circ} \mathrm{C}$. & ${ }^{\circ} \mathrm{C}$. & $\circ \dot{C}$ & ${ }^{\circ} \mathrm{C}$. & ${ }^{\circ} C$. \\
\hline 40.58 & 25 & 40.7 & 25 & 35.4 & 25 & 35.85 & 25 \\
\hline 40.30 & 24 & 40.2 & 16 & 34.8 & 24 & 34.40 & 16 \\
\hline 40.68 & 25 & 40.5 & 24 & 35.3 & 22 & 34.90 & 22 \\
\hline $\begin{array}{l}40.58 \\
41.13\end{array}$ & 26 & 40.45 & 26 & 34.9 & 25 & 34.87 & 26 \\
\hline 41.00 & 27 & 40.8 & 25 & & & 34.6 & 27 \\
\hline 41.00 & 31 & & & 34.4 & 32 & & $\ldots$ \\
\hline 40.33 & 28 & 40.28 & 28 & 35.26 & 28 & 35 & 28 \\
\hline 41.00 & 28 & 40.90 & 25 & a 32.90 & 27 & 36.75 & 26 \\
\hline 40.90 & & & & 33.9 & & & \\
\hline 40.40 & & & & 34.45 & & & \\
\hline 40.37 & & & & 34.17 & & & \\
\hline 40.55 & & & & 34.89 & & & \\
\hline 40.59 & 28 & & & 34.74 & 29 & & \\
\hline $\begin{array}{l}40.70 \\
40.20\end{array}$ & 24 & $\begin{array}{l}40.7 \\
39.68\end{array}$ & 20 & $\begin{array}{l}35.50 \\
35.0\end{array}$ & 21 & $\begin{array}{l}35.6 \\
34.9\end{array}$ & 21 \\
\hline & $\ldots$ & 40.89 & 23 &. & & 35.25 & 23 \\
\hline 40.80 & & & & 35.3 & & & - \\
\hline 40.60 & 30 & & & 35.1 & 30 & & \\
\hline 40.30 & 22 & & & 34.7 & 22 & & \\
\hline $\begin{array}{l}40.72 \\
40.22\end{array}$ & & & & & & $\begin{array}{r}b 34.4 \\
\ldots \ldots \ldots\end{array}$ & \\
\hline …. & & 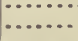 & ..... & $\begin{array}{l}34.09 \\
33.90\end{array}$ & & $\cdot$ & -. \\
\hline 40.62 & .. & 40.50 & $\ldots$ & 34.7 & & 35.14 & ... \\
\hline $\begin{array}{l}41.13 \\
40.20\end{array}$ & & $\begin{array}{l}40.90 \\
39.68\end{array}$ & & $\begin{array}{l}32.9 \\
32\end{array}$ & & $\begin{array}{l}36.85 \\
34.40\end{array}$ & $\mid \begin{array}{l}\cdots \\
\ldots \ldots\end{array}$ \\
\hline .93 & 0 & 1.22 & & 2.6 & ...... & 2.45 & \\
\hline
\end{tabular}

$b$ Not corrected for stem exposure. 
TABLE II.-Results of cooperative work on the titer test for 1904-Dalican method of stirring.

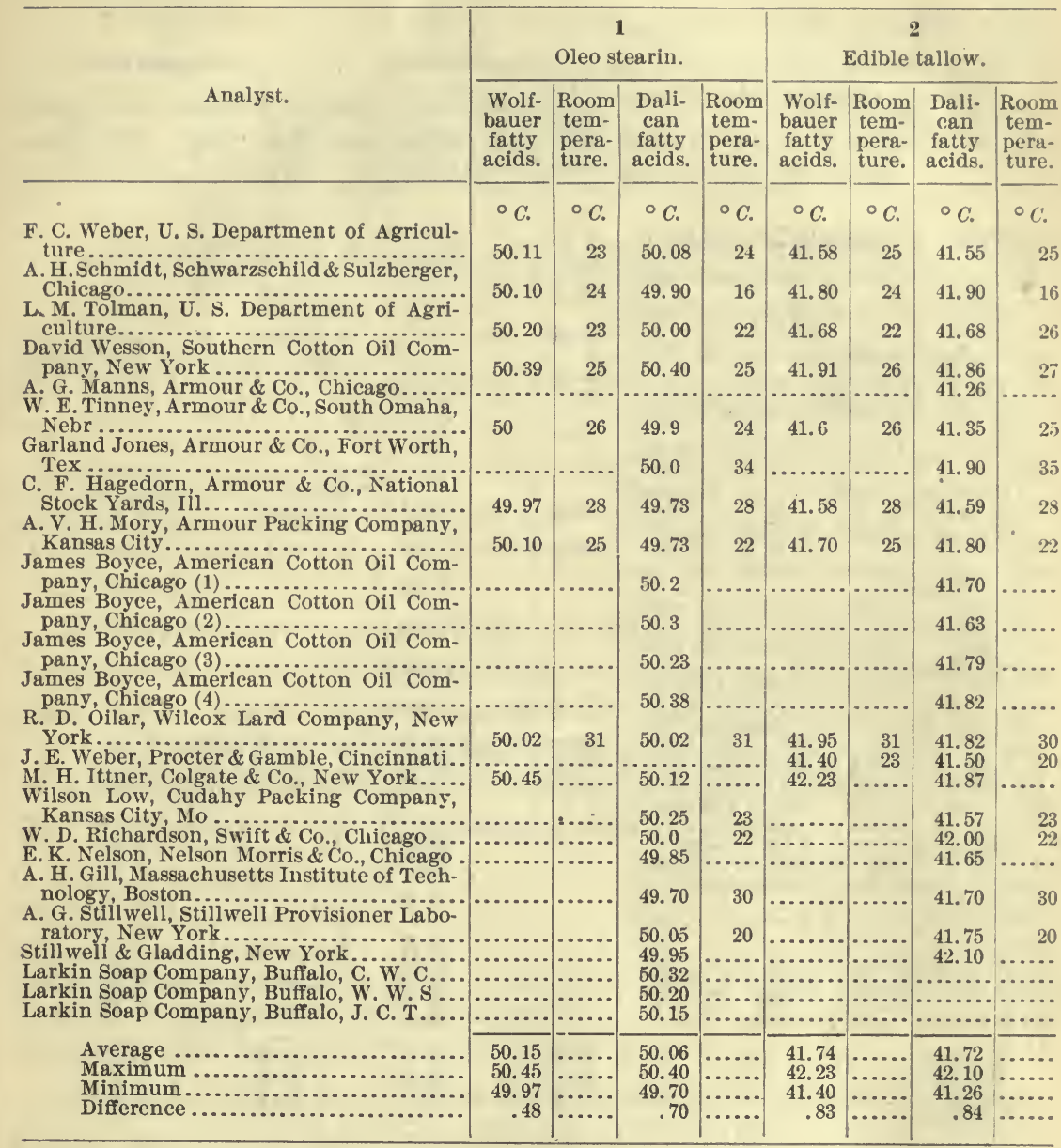


TABLE II.-Results of cooperative work on the titer test for 1904-Dalican method of stirring-Continued.

Analyst.

A.H. Schmidt, Schwarzschild \& Sulzberger,

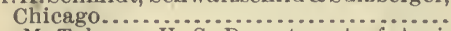

L. M. Tolman, U. S. Department of Agriculture..........................................

David Wesson, Southern Cotton Oil Com-

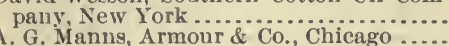

W. E. Tinney, Armour \& Co., South Omaha, Garland Jones, Armour \& Co., Fort Worth, Stock Yards, Ill........................

A. V. H. Mory, Armour Packing Company, Kansas City ........................... James Boyce, American Cotton Oil Com-

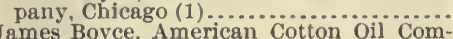
James Boyce, American Cotton Oil ComJames Boyce, American Cotton Oil Company, Chicago (3) ...........................
James Boyce, American Cotton Oil Com-

R. D. Oilar, Wilcox Lard Company, New

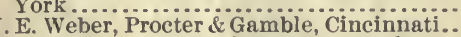
if. H. Ittner, Colgate \& Co., New York.... Wilson Low, Cudahy Packing Company. Kansas City, Mo ...................................

W. D. Richardson, Swift \& Co., Chicago ....

A. H. Gill, Massachusetts Institute of Technology, Boston.

A. G. Still well, Stillwell Provisioner Laboratory, New York.

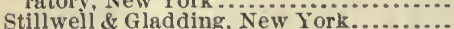

Larkin Soap Company, Buffalo, C. W. C.

Larkin Soap Company, Buffalo, W. W. S.

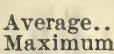

Minimum.

Difference
F. C. Weber, U. S. Department of AgriculTex ................................... National

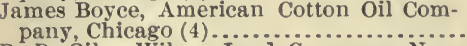

\begin{tabular}{|c|c|c|c|c|c|c|c|}
\hline & Yellow & grease. & & & Cotton- & eed oil. & \\
\hline $\begin{array}{c}\text { Wolf- } \\
\text { bauer } \\
\text { fatty } \\
\text { acids. }\end{array}$ & \begin{tabular}{|c|} 
Room \\
tem- \\
pera- \\
ture-
\end{tabular} & $\begin{array}{l}\text { Dali- } \\
\text { can } \\
\text { fatty } \\
\text { acids. }\end{array}$ & $\begin{array}{l}\text { Room } \\
\text { tem- } \\
\text { pera- } \\
\text { ture. }\end{array}$ & $\begin{array}{l}\text { Wolf- } \\
\text { bauer } \\
\text { fatty } \\
\text { acids. }\end{array}$ & $\begin{array}{l}\text { Room } \\
\text { tem- } \\
\text { pera- } \\
\text { ture. }\end{array}$ & $\begin{array}{l}\text { Dali- } \\
\text { can } \\
\text { fatty } \\
\text { acids. }\end{array}$ & $\begin{array}{l}\text { Room } \\
\text { tem- } \\
\text { pera- } \\
\text { ture. }\end{array}$ \\
\hline${ }^{\circ} C$. & ${ }^{\circ} \mathrm{C}$. & ${ }^{\circ} C$. & ${ }^{\circ} \mathrm{C}$. & ${ }^{\circ} \mathrm{C}$. & ${ }^{\circ} \mathrm{C}$. & ${ }^{\circ} \mathrm{C}$. & $\circ C$ \\
\hline 39.78 & 25 & 39.3 & 25 & 33.93 & 25 & 33.75 & 24 \\
\hline 39.40 & 24 & 39.7 & 16 & 33.80 & 34 & 33.60 & 16 \\
\hline 39.90 & 25 & 39.5 & 22 & 34.05 & 25 & 33.85 & 21 \\
\hline 39.60 & 27 & $\begin{array}{l}39.57 \\
38.72\end{array}$ & 27 & 33.35 & 26 & 33.31 & 26 \\
\hline 39.5 & 26 & 39.3 & 25 & & & 32.3 & 27 \\
\hline & & 40.1 & 35 & & & 33.5 & 25 \\
\hline 39.62 & 28 & 39.17 & 28 & 33.74 & 28 & 33.92 & 28 \\
\hline 39.40 & 25 & 39.50 & 24 & 31.75 & 25 & 33.55 & 25 \\
\hline & & 39.50 & & & & 33.60 & \\
\hline & & 39.30 & & & & 33.60 & \\
\hline & & 39.83 & & & & 33.26 & \\
\hline & & 39.98 & & & & 33.83 & \\
\hline 39.69 & 29 & 39.43 & 28 & 33.16 & 31 & 3. & 31 \\
\hline & 21 & 6 & 21 & 33.10 & 19 & 33.10 & 21 \\
\hline & & & & & & & \\
\hline & . & 39.85 & 23 & & & & 23 \\
\hline & $\because$ & $\begin{array}{l}40.20 \\
39.75\end{array}$ & & & & $\begin{array}{l}34.10 \\
35.55\end{array}$ & 22 \\
\hline & & 39.60 & & & & 34.30 & 30 \\
\hline & & 39.75 & 25 & & & 33. 70 & 25 \\
\hline & & 39.50 & ....... & . & & 33.40 & . \\
\hline & & $\begin{array}{l}38.76 \\
38.92\end{array}$ & & & & & ... \\
\hline & & 38.95 & & & & 33.76 & \\
\hline 39.66 & . & 39. & . & 33.43 & •. & 33.57 & \\
\hline 40.15 & & 40.20 & & 34.05 & & 34.30 & \\
\hline $\begin{array}{r}39.40 \\
.75\end{array}$ & $\ldots$ & $\begin{array}{r}38.72 \\
1.48\end{array}$ & $\cdots$ & $\begin{array}{r}31.75 \\
2.30\end{array}$ & ..... & $\begin{array}{r}32.3 \\
2.0\end{array}$ & ... \\
\hline & & & & & & & \\
\hline
\end{tabular}

A study of the results in Tables I and II leads to the following conclusions:

(1) Different analysts do not obtain closely concordant results with either method. This fact is doubtless due to several causes. Differences in room temperature affect results, as will be shown later in the work of F. C. Weber, Thomas Gladding, and R. D. Oilar. The use of different thermometers also affects the results, and the correction given for the stem exposure is not strictly accurate for all thermometers. But the average of all the results shows remarkahle agreement, indicating that the variations were as often high as low.

(2) Individual analysts obtained very closely corresponding results with the fatty acids prepared by either method, showing that under the same conditions satisfactory agreement can be obtained, and that 
the method of preparation of the fatty acids need not be uniform but may be optional with the analyst.

(3) Variations of the methods of stirring were found to give very different figures. The Wolfbauer scheme of constant stirring until the thermometer stopped falling gave uniformly higher results, as was shown last year. In addition to the data given in Tables I and II, the following results obtained by M. H. Ittner are of value:

TABLE III.-Titer tests by M. H. Ittner, using special method of stirring and different methods of preparation.

\begin{tabular}{|c|c|c|c|c|c|c|c|c|}
\hline \multirow{2}{*}{$\begin{array}{l}\text { Method of preparation of the fatty } \\
\text { acids. }\end{array}$} & \multicolumn{2}{|c|}{ No. 1.} & \multicolumn{2}{|c|}{ No. 2.} & \multicolumn{2}{|c|}{ No. 3.} & \multicolumn{2}{|c|}{ No. 4.} \\
\hline & $\begin{array}{l}\text { Aver- } \\
\text { age. }\end{array}$ & $\begin{array}{l}\text { Maxi- } \\
\text { mum. }\end{array}$ & $\begin{array}{l}\text { Aver- } \\
\text { age. }\end{array}$ & $\begin{array}{l}\text { Maxi- } \\
\text { mum. }\end{array}$ & $\begin{array}{l}\text { Aver- } \\
\text { age. }\end{array}$ & $\begin{array}{l}\text { Maxi- } \\
\text { mum. }\end{array}$ & $\begin{array}{l}\text { A ver- } \\
\text { age. }\end{array}$ & $\begin{array}{l}\text { Maxi- } \\
\text { mum. }\end{array}$ \\
\hline Dalican method .................... & $\begin{array}{l}\circ{ }^{\circ} \mathrm{C} . \\
50.71\end{array}$ & ${ }^{\circ}{ }_{50.80}$ & ${ }_{4}^{\circ} C_{4}$ & $\begin{array}{l}\circ{ }^{\circ} \mathrm{C} . \\
42.55\end{array}$ & $\begin{array}{l}\circ C . \\
41.00\end{array}$ & $\begin{array}{l}\circ{ }^{\circ} C_{.} \\
41.05\end{array}$ & ${ }^{\circ} \mathrm{C}$. & $\begin{array}{l}{ }^{\circ} \mathrm{C} . \\
36.15\end{array}$ \\
\hline $\begin{array}{l}\text { Wolfbauer method but not dried } \\
4 \text { hours at } 105^{\circ} \mathrm{C}\end{array}$ & 50.71 & 50.75 & 42.55 & 42.65 & 41.00 & 41.20 & 36.00 & 36.05 \\
\hline 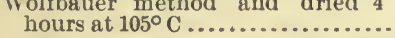 & 50.80 & 50.85 & 42.62 & 42.65 & 41.05 & 41.15 & 36.15 & 36.20 \\
\hline
\end{tabular}

The figures given are averages of three determinations and the results show that these three methods of preparing the fatty acids do not affect the titer. Other's reported the same experience.

W. D. Richardson reports the following results, which indicate that after the fatty acids are dried by filtering very little effect is caused by drying at $105^{\circ} \mathrm{C}$. The Wolfbauer method was used:

Not washed, filtered, nor dried

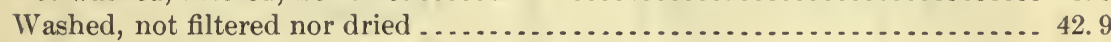

Washed, filtered, not dried .................................... 43.2

Washed, filtered, dried at $105^{\circ} \mathrm{C}$. for 10 minutes...................... 43.2

Washed, filtered, dried at $105^{\circ} \mathrm{C}$. for 20 minutes........................ 43.4

Washed, filtered, dried at $105^{\circ} \mathrm{C}$. for 30 minutes...................... 43.4

All these results agree with those obtained by Wolfbauer, who concluded that the method of saponification did not affect the titer, providing that the alcohol is completely removed in alcoholic saponification. A. V. H. Mory, however, calls attention to the fact that there is greater danger of scorching the fat by the Wolfbauer method of saponification, but finds that if the soaps are carried down to dryness over an asbestos sheet this contingency can be avoided. The scorching of the fat reduced the titer to a considerable extent, as is shown in the following table:

TABLE IV.-Effect on titer of scorching the soaps, by A. V. H. Nory.

\begin{tabular}{|c|c|c|c|c|c|}
\hline Conditions. & $\begin{array}{l}\text { Oleo } \\
\text { stearin. }\end{array}$ & Tallow. & $\begin{array}{l}\text { Brown } \\
\text { grease. }\end{array}$ & $\begin{array}{l}\text { Tallow } \\
\text { oil. }\end{array}$ & Lard oil. \\
\hline $\begin{array}{l}\text { Not scorched... } \\
\text { Scorched ........ }\end{array}$ & $\begin{array}{l}{ }^{\circ} C . \\
50.50 \\
50.60\end{array}$ & $\begin{array}{l}{ }^{\circ} \mathrm{C} . \\
42.50 \\
42.15\end{array}$ & $\begin{array}{l}{ }^{\circ} C . \\
41.70 \\
41.50\end{array}$ & $\begin{array}{l}{ }^{\circ} \mathrm{C} . \\
39.20 \\
38.75\end{array}$ & $\begin{array}{l}{ }^{\circ} C . \\
34.55 \\
33.75\end{array}$ \\
\hline
\end{tabular}


These fats were only slightly browned. Mr. Mory found that cottonseed oil was very easily affected and the titer lowered to a considerable extent. In investigating the effect of sulphuric acid on the freed acids it was found that the titer was not changed. Mr. Mory also made a number of interesting determinations showing the effect of remelting the fatty acids prepared by the Dalican method, and by heating to $150^{\circ} \mathrm{C}$., as a method of drying, instead of drying four hours at $105^{\circ} \mathrm{C}$. The fatty acids are placed in a beaker and heated to $150^{\circ} \mathrm{C}$., stirring constantly. The figures giren in Table $\mathrm{V}$ do not show any material effect from heating, at least where the Wolfbauer method of stirring was used. Table VI shows the effect of remelting the fatty acids prepared by different methods of saponification. 


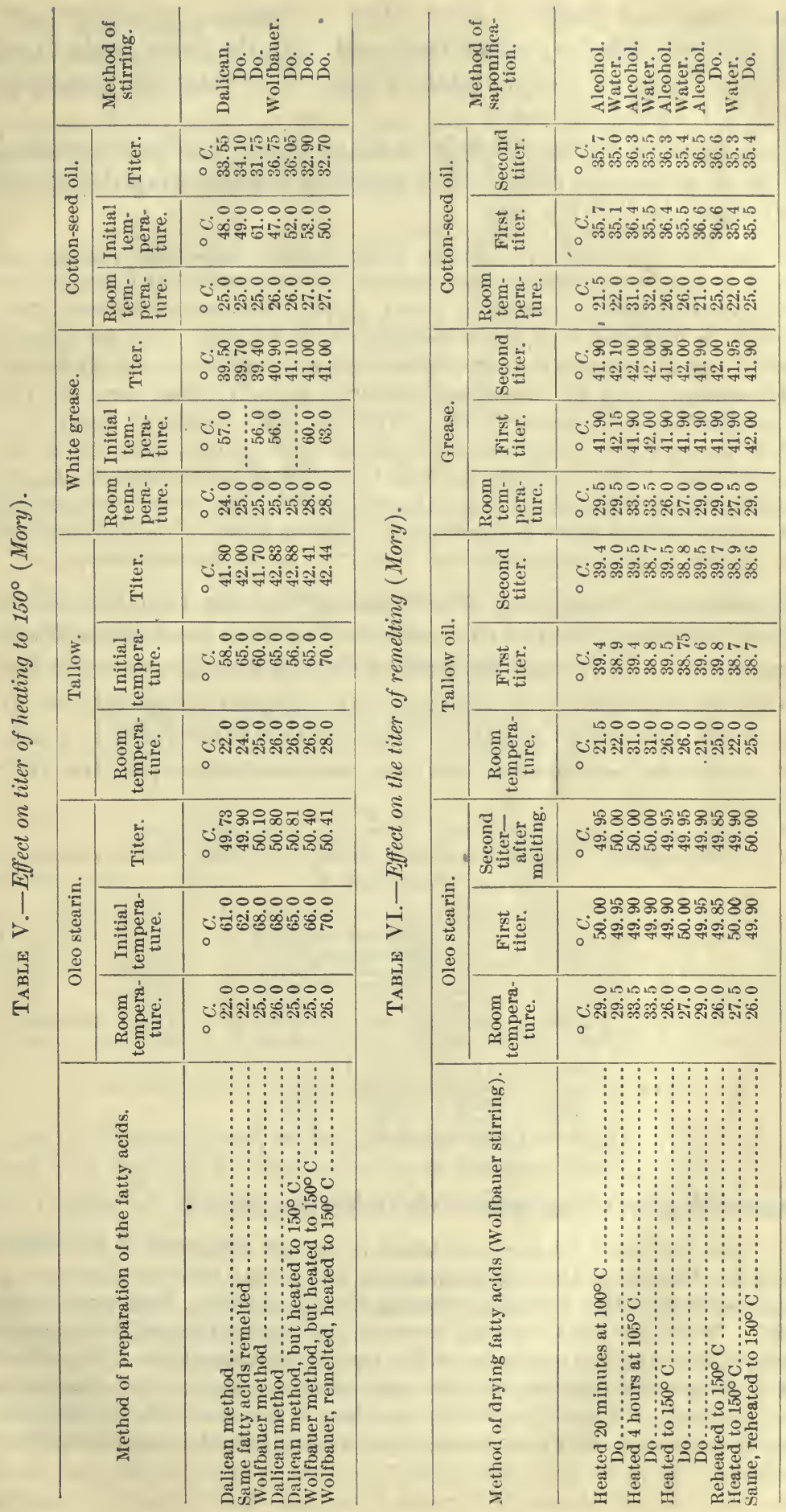


These results show that the same titer is, obtained, no matter how the fatty acids are dried, on remelting, and that the fatty acids dried by filtering and drying on the water bath give the same titer as when dried at $105^{\circ} \mathrm{C}$. for four hours.

Thomas Gladding argues strongly in favor of the Wolfbauer method of stirring, as he finds it gives better results when there is a difference in room temperature. He says:

We find that on a high-titer fat when the crystallization takes place sharply and rapidly there is but little difference between the two methods, but in fats of low titers, where crystallization is sluggish, a very marked difference is found. This difference is to be expected from the circumstances of the case. In a low-titer fat the lower and outside layers in the test tube become practically solid, the crystallization is there complete and all heat of crystallization is lost in these portions. We now stir together this cold mass and mix it with the small portion of liquid fat in the center of the test tube. It can not be expected that the heat given out by the slow crystallization of this small fraction will be sufficient to overcome the loss of heat by radiation and at the same time raise the temperature of the portions that have sunk several degrees below the titer point. This method is unscientific, inaccurate, and certain to give results from $0.5^{\circ} \mathrm{C}$. to $1^{\circ} \mathrm{C}$. below the true titer point.

It is urged most strongly by Mr. Gladding that the Dalican method be modified by the adoption of the method of stirring used in the Wolfbauer procedure. In further support of this method he gives the following experiments made in February, at different temperatures, in one case in the laboratory room and immediately afterwards in a cold room, to ascertain the effect of varying temperatures upon the titer test:

TABLE VII.-Comparison of effect of temperature in connection with different methods of stirring (Gladding).

\begin{tabular}{|c|c|c|c|}
\hline \multicolumn{2}{|c|}{ Dalican method. } & \multicolumn{2}{|c|}{$\begin{array}{l}\text { Dalican method } \\
\text { with constant stir } \\
\text { ring, as per Wolf- } \\
\text { bauer method. }\end{array}$} \\
\hline $45^{\circ} \mathrm{F}$. & $65^{\circ} \mathrm{F}$. & $45^{\circ} \mathrm{F}$. & $65^{\circ} \mathrm{F}$. \\
\hline $\begin{array}{l}\circ C . \\
48.75 \\
42.60 \\
48.95 \\
43.40\end{array}$ & $\begin{array}{l}\circ C . \\
49.00 \\
42.80 \\
49.15 \\
43.55\end{array}$ & $\begin{array}{l}{ }^{\circ} C . \\
49.05 \\
42.90 \\
49.32 \\
43.55\end{array}$ & $\begin{array}{l}{ }^{\circ} C . \\
49.05 \\
42.90 \\
49.35 \\
43.55\end{array}$ \\
\hline
\end{tabular}

\section{In commenting on these results Mr. Gladding says: •}

It will be seen that while temperature makes a marked difference in the results when using the Dalican method of stirring, but little if any difference is found at different temperatures when using the constant stirring method. This result might be expected. When the mass is stirred constantly it begins to crystallize throughout the whole body at a few tenths below the true crystallizing point. The whole mass is of a uniform temperature, and the heat given out by the crystallization is sufficient to overcome the loss of radiation, regardless of moderate differences of outside temperatures, and to secure at the center of the test tube the true crystallizing or titer point. 
The following results by F. C. Weber of this laboratory confirm these conclusions and show that the Dalican method of determining the titer is affected to a much greater degree by room temperature than the Wolfbauer method, as might be expected; but Weber's results also indicate that a standard temperature for fats having a low titer is desirable for the Wolfbauer method of stirring as well.

TABLE VIII.-Effect of room temperature on titer ( $F$. C. Weber).

[Figures are the average of several determinations.]

\begin{tabular}{|c|c|c|c|c|c|c|c|c|c|c|c|c|}
\hline \multirow{3}{*}{ Fat. } & \multicolumn{6}{|c|}{ Dalican method. } & \multicolumn{6}{|c|}{ Wolfbauer method. } \\
\hline & \multicolumn{3}{|c|}{. Titer. } & \multicolumn{3}{|c|}{ Difference. } & \multicolumn{3}{|c|}{ Titer. } & \multicolumn{3}{|c|}{ Difference. } \\
\hline & $5^{\circ} \mathrm{C}$ & $20^{\circ} \mathrm{C}$. & $30^{\circ} \mathrm{C}$. & $\begin{array}{l}5^{\circ} 10 \\
20^{\circ} .\end{array}$ & $\begin{array}{c}20^{\circ} \text { to } \\
30^{\circ} .\end{array}$ & $\mid \begin{array}{l}5^{\circ} \text { to } \\
30^{\circ}\end{array}$ & $5^{\circ} \mathrm{C}$ & $20^{\circ} \mathrm{C}$. & $30^{\circ} \mathrm{C}$. & $\begin{array}{l}5^{\circ} \text { to } \\
20^{\circ} .\end{array}$ & $\mid \begin{array}{c}20^{\circ} \text { to } \\
30^{\circ} .\end{array}$ & $\begin{array}{l}5^{\circ} \text { to } \\
30^{\circ} \text {. }\end{array}$ \\
\hline 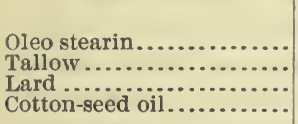 & $\begin{array}{l}{ }^{\circ} C . \\
50.1 \\
41.0 \\
39.2 \\
32.9\end{array}$ & $\begin{array}{l}{ }^{\circ} \mathrm{C} . \\
50.1 \\
41.5 \\
39.6 \\
33.4\end{array}$ & $\begin{array}{l}{ }^{\circ} \mathrm{C} . \\
50.3 \\
41.8 \\
40.0 \\
34.1\end{array}$ & $\begin{array}{r}{ }^{\circ} \mathrm{C} . \\
0.0 \\
+\quad .5 \\
+.4 \\
+.5\end{array}$ & $\begin{array}{r}{ }^{\circ} \mathrm{C} . \\
+0.2 \\
+.3 \\
+.4 \\
+.7\end{array}$ & $\begin{array}{r}{ }^{\circ} \mathrm{C} \\
+0.2 \\
+.8 \\
+.8 \\
+1.2\end{array}$ & $\begin{array}{l}{ }^{\circ} \mathrm{C} . \\
50.6 \\
42.1 \\
40.5 \\
34.6\end{array}$ & $\begin{array}{l}{ }^{\circ} \mathrm{C} . \\
50.6 \\
42.2 \\
40.6 \\
34.9\end{array}$ & $\begin{array}{l}{ }^{\circ} C . \\
50.6 \\
42.3 \\
40.7 \\
35.3\end{array}$ & $\begin{array}{r}{ }^{\circ} \mathrm{C} \\
0.0 \\
+\quad .1 \\
+.1 \\
+.3\end{array}$ & $\begin{array}{r}{ }^{\circ} C . \\
0.0 \\
+.1 \\
+.1 \\
+.4\end{array}$ & $\begin{aligned} & \\
& C . \\
& 0.0 \\
&+.2 \\
&+.2 \\
&+.7\end{aligned}$ \\
\hline
\end{tabular}

R. D. Oilar reached much the same conclusion as to the effect of room temperature on the titer, but does not find that the Wolfbauer method gives better results than the Dalican.

TABLE IX-Effect of room temperature on titer (R. D. Oilar).

\begin{tabular}{|c|c|c|c|c|c|c|c|c|c|c|c|}
\hline \multirow[b]{2}{*}{ Fat. } & \multicolumn{5}{|c|}{ Dalican stirring. } & \multicolumn{5}{|c|}{ Wolfbauer stirring. } & \multirow[b]{2}{*}{$\begin{array}{l}\text { Method of } \\
\text { preparation } \\
\text { of the fatty } \\
\text { acids. }\end{array}$} \\
\hline & Titer. & $\begin{array}{l}\text { Room } \\
\text { tem- } \\
\text { pera- } \\
\text { ture. }\end{array}$ & Titer. & \begin{tabular}{|c|} 
Room \\
tem- \\
pera- \\
ture.
\end{tabular} & $\begin{array}{l}\text { Dif- } \\
\text { fer- } \\
\text { ence. }\end{array}$ & Titer. & $\begin{array}{c}\text { Room } \\
\text { tem- } \\
\text { pera- } \\
\text { ture. }\end{array}$ & Titer. & $\begin{array}{c}\text { Room } \\
\text { tem- } \\
\text { pera- } \\
\text { ture. }\end{array}$ & $\begin{array}{l}\text { Dif- } \\
\text { fer- } \\
\text { ence. }\end{array}$ & \\
\hline & ${ }^{\circ} \mathrm{C}$. & ${ }^{\circ} \mathrm{C}$. & ${ }^{\circ} \mathrm{C}$. & ${ }^{\circ} \mathrm{C}$. & ${ }^{\circ} \mathrm{C}$. & ${ }^{\circ} \mathrm{C}$ & ${ }^{\circ} \mathrm{C}$. & ${ }^{\circ} \mathrm{C}$. & ${ }^{\circ} \mathrm{C}$ & ${ }^{\circ} \mathrm{C}$. & \\
\hline Oleo stearin . & 49.77 & 14 & 50.12 & 32 & +0.35 & 49.99 & 14 & 50.73 & 32 & +0.74 & Wolfbauer. \\
\hline Do............ & 49.88 & 13 & 50.22 & 30 & +.34 & 50.60 & 13 & 50.84 & 29 & +.24 & Dalican. \\
\hline Tallow ... & 41.60 & 14 & 41.99 & 31 & +.39 & 42.30 & 14 & 42.40 & 31 & +.10 & Wolfbauer. \\
\hline Do............ & 41.23 & 13 & 41.74 & 28 & +.51 & 41.93 & 13 & 42.34 & 29 & +.41 & Dalican. \\
\hline Grease........... & 39.37 & 14 & 39.76 & 32 & +.39 & 40.46 & 14 & 40.73 & 30 & +.37 & Wolfbauer. \\
\hline Do............. & 39.28 & 13 & 39.50 & 28 & +.22 & 40.27 & 13 & 40.59 & 28 & +.32 & Dalican. \\
\hline Cotton-seed oil $a$. & 32.73 & 14 & 33.65 & 29 & +.92 & 34.99 & 14 & 34.82 & 27 & -.07 & Wolfbauer. \\
\hline Do. $a . . . . .$. . & 31.54 & 13 & 31.61 & 26 & +.07 & 32.71 & 13 & 33.95 & 30 & +1.24 & Dalican. \\
\hline
\end{tabular}

a A different sample of cotton-seed oil was used in each of these determinations.

David Wesson takes much the same position as the result of his own work and that of his assistants, and his conclusions are quoted from the report of Mr. Ayer, chemist in charge of the laboratory at Savannah, Ga.:

1. The method of saponification makes practically no difference in the resulting titer. We prefer the Wolfbauer method as being surer, more rapid, less expensive, and less liable to accident from fire.

2. We prefer to dissolve the soap in hot water and throw out the fatty acids, as in the Dalican method, rather than to follow the method laid down in the Wolfbauer procedure.

3. The Wolfbauer stirring gives results from $0.5^{\circ}$ to $1.5^{\circ}$ higher than the Dalican. This is to be expected, as in the latter case a large portion of the fatty acids has solidified and cooled below the temperature of the remaining liquid fat, and this, 
upon being stirred in, chills the mixture and neutralizes much of the heat that is freed by the crystallizing fat.

In the Wolfbauer method the constant stirring keeps the temperature uniform throughout the mass, and there is no sudden cooling such as is unavoidable in the Dalican procedure. The lower the titer point the more noticeable are these differences.

I would therefore recommend the Wolfbauer method of stirring as giving results nearer the true titer point.

Unfortunately the method, in the writer's opinion, is trying and tedious, but from the results obtained no hesitancy is felt in recommending the adoption of the Wolfbauer method of determining the titers.

J. E. Weber finds that the method of saponification has no influence on the titer, but thinks that the Wolfbauer method of stirring is the more reliable for all kinds of titers, and gives his reasons as follows:

The Dalican method was found easy to handle, because it gives definite instructions as to when to start and stop stirring; the Wolfbauer method leaves more to individual judgment, but these difficulties are very slight for an experienced chemist. While the Dalican method is reliable for the two harder stocks, it became less so for the others and caused some difficulty, even with the cotton-seed oil. By experiment it was found that for very low titers this method gives no definite result and can not be used at all. We have to determine all kinds of stock and titers, and often must use ice, and even ice with salt, during the determination. The Wolfbauer method (with our modification) never fails us. It is true with very low titers, $1.5^{\circ}$ or $2^{\circ} \mathrm{C}$., that the duplicates are not so very sharp, but are still within $0.5^{\circ}$. Putting aside all speculations as to what the titers-especially the low ones-mean, the Wolfbauer method gives comparable figures for low and high titers, and that is what the trade needs and is demanding.

This desire to get comparable figures resulted also in increasing the diameter of the titer tube. A tube 1 inch in diameter does not give definite results with very low titers; therefore the extra tall beaker ( 5 ounces) of the trade was chosen, the average diameter of which is about $45 \mathrm{~mm}$. The larger amount of fatty acids cools off more slowly, giving the thermometer more time to become stationary and rise, and it is possible to get a titer of $1.5^{\circ} \mathrm{C}$. We have adopted this beaker for all the titer work, its only disadvantage being that more fatty acids and larger samples of stock must be used.

To determine the influence of the larger volume of fatty acids, we determined the titer of tallow-fatty acids (from our stock)-in three different tubes or beakers. Each figure in the following results is the average of two determinations:

$42.325^{\circ}$ in tube $25 \mathrm{~mm}$ diameter (Wolfbauer).

$42.425^{\circ}$ in beaker $45 \mathrm{~mm}$ diameter.

$42.575^{\circ}$ in beaker $70 \mathrm{~mm}$ diameter.

Evidently there is an increase in the titer along with the increase of the diameter, but it is small and of no importance. The $25 \mathrm{~mm}$ tube can not be used for very low titers, the $45 \mathrm{~mm}$ gives satisfactory results and is also easy to handle, while the $70 \mathrm{~mm}$ beaker is very unhandy.

R. D. Oilar, in Table X, shows to what an extent the diameter of the tube affects the titer. The Dalican method seems less affected by the diameter of the tube than the Wolfbauer. 
TABLE X.-Effect of diameter of tube on the titer (R. D. Oilar).

\begin{tabular}{|c|c|c|c|c|c|c|}
\hline \multirow[b]{2}{*}{$\begin{array}{l}\text { Diameter } \\
\text { of tube. }\end{array}$} & \multicolumn{3}{|c|}{ Wolfbauer stirring. } & \multicolumn{3}{|c|}{ Dalican stirring. } \\
\hline & Titer. & $\begin{array}{l}\text { Room } \\
\text { temper- } \\
\text { ature. }\end{array}$ & Increase. & Titer. & \begin{tabular}{|l} 
Room \\
temper- \\
ature.
\end{tabular} & Increase. \\
\hline $\begin{array}{c}m m \\
-\quad 22 \\
27 \\
36 \\
42 \\
51 \\
60 \\
77\end{array}$ & $\begin{array}{l}\circ C . \\
41.87 \\
42.19 \\
42.53 \\
42.69 \\
42.74 \\
42.81 \\
42.88\end{array}$ & $\begin{array}{l}{ }^{\circ} C \\
25 \\
26 \\
26 \\
27 \\
27 \\
26 \\
20\end{array}$ & $\begin{array}{r}{ }^{\circ} . \\
\ldots . .3 . \\
0.32 \\
.34 \\
.16 \\
.05 \\
.07 \\
.07\end{array}$ & $\begin{array}{l}\circ C . \\
41.54 \\
41.69 \\
42.04 \\
42.11 \\
42.14 \\
42.14 \\
42.10\end{array}$ & $\begin{array}{l}{ }^{\circ} C . \\
25 \\
25 \\
26 \\
25 \\
24 \\
26 \\
24\end{array}$ & $\begin{array}{r}\circ C . \\
\cdots .13 \\
.35 \\
.07 \\
.03 \\
.00 \\
-.04\end{array}$ \\
\hline
\end{tabular}

A. G. Manns makes the following report as to the different methods of preparing the fatty acids:

Broadly speaking, the Dalican method gives lower results than the Wolfbauer method, the difference being greater the lower the titer of the sample under examination. Furthermore, the Dalican test gives, in this laboratory, fatty acids the titer of which is higher each time it is retested, presumably because of the loss of moisture caused by the remelting of the sample prior to each test. On the other hand, the Wolfbauer method gives fatty acids, the titer of which is so definite that it can easily be duplicated, and will give very close agreement in different hands if tested in accordance with the method.

I have repeatedly found this to be true when the same sample of fatty acids was tested at this laboratory and at one or more of our branch laboratories. This is due, however, only to the fact that the method as used in this laboratory, and described in your circular of February 24, 1904, gives a definite point at which to stop stirring.

I find, further, that the fatty acids from the Wolfbauer method, after having stood for some time, should be heated to $150^{\circ} \mathrm{C}$. prior to retesting; if they were simply remelted at a low temperature, the titer was found quite uniformly to be lower than when first tested; if they had been previously heated to $150^{\circ} \mathrm{C}$., the titer was found to agree with the first test. This condition is probably due to absorbed moisture.

A. V. H. Mory sends in the following very interesting results on the effect of incomplete saponification on the titer:

TABLE XI.-Effect of incomplete saponification on the titer test (Mory).

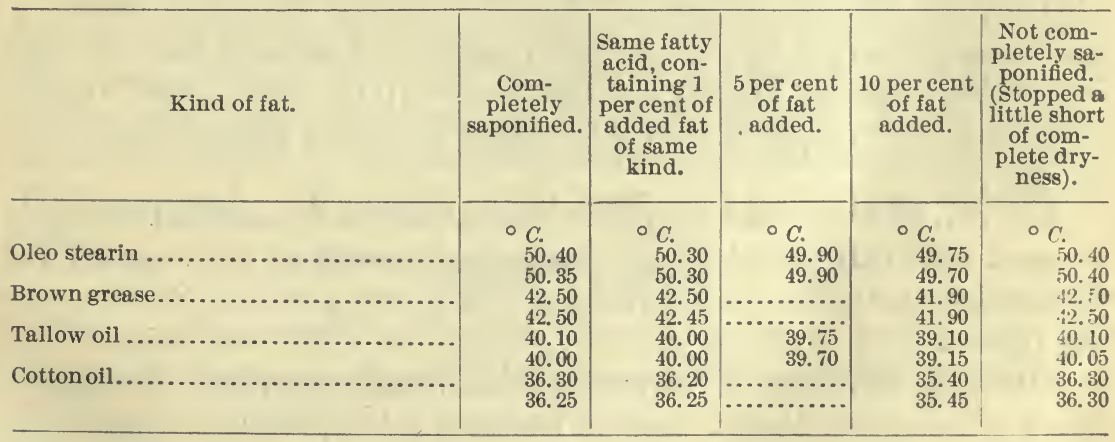

In every case except that of the brown grease the ammonia-treated alcoholic solutions of the acids, obtained by stopping the saponification process short of completion, was less cloudy than that obtained from the mixture containing 1 per cent of fat. It was necessary to stop the evaporation much sooner in the case of the brown 
grease to avoid complete saponification, and the resulting fatty acids showed up a little cloudier than the 1 per cent mixture; still we could not detect it in the titer.

It appears, then, that the error in the titer due to accidental failure to completely saponify is ordinarily a negligible quantity. In the case of doubt, comparison by the saponification test with a stock mixture of fatty acids and fat containing 1 per cent of the latter can easily be made, when any sample showing no greater cloudiness than this may be assumed to be not more than $0.1^{\circ} \mathrm{C}$. lower in titer. The range in the titer and general properties of the samples employed in the experiment seemed wide enough to warrant such a generalization.

'These facts would seem to justify the referee in recommending a method combining the best features of both methods, as follows:

PREPARATION OF FATTY ACIDS.

Saponify by using aqueous or alcoholic potassium or sodium hydrate. If alcohol is used it must be carefully removed. Dry the fatty acids in the manner prescribed in the Dalican method, although they may be dried as in the Wolfbauer method if desired.

Always test the fatty acids for unsaponified matter, as prescribed by the Wolfbauer method. The titer shall be taken in the manner described in the Wolfbauer method and in the tubes prescribed. The room temperature should be reported.

A letter was sent to the collaborators asking them to give their opinion of this method as outlined, and the following signified their willingness to accept it:

A. Lowenstein, chemist of Nelson Morris \& Co.

Wilson Low, chemist Cudahy Packing Company.

David Wesson, Southern Cotton Oil Company.

Thomas Gladding, of Stillwell \& Gladding.

A. G. Stillwell, of the Stillwell Provisioner Laboratory.

F. C. Weber, of the U. S. Department of Agriculture.

M. H. Ittner, Colgate \& Co.

James Boyce, of the American Cotton Oil Company, and R. D. Oilar, of the W. J. Wilcox Lard Company, felt that the Dalican method of stirring was more satisfactory.

Dr. A. G. Manns, of Armour \& Co., and his associates desired a more complete drying of the fatty acids and showed that in their experiments simply heating the fatty acids up to $150^{\circ} \mathrm{C}$. and stirring constantly was sufficient, giving the same results as heating four hour's at $105^{\circ} \mathrm{C}$.

A. V. H. Mory wished to specify that alcoholic saponification should be used with cottonseed oil, the dangers of scorching the soap by the Wolfbauer method of saponitication being very great, as is shown by his report.

Albert H. Schmidt, of Schwarzchild \& Sulzberger, was strongly in favor of using the Dewar racuum jacketed tube specially arranged for the titer work and constantly shaking. This arrangement certainly offer's many advantages of convenience and accuracy, and his suggestion as to the need of standard thermometers is important. 
The general opinion of the collaborators is that the constant stirring method of obtaining the titer is the most satisfactory and that the method of saponification is immaterial. The chief point of nonagreement is on the drying of the fatty acids.

\section{CONCLUSIONS.}

In conclusion, it seems to the referee that the work of this year has brought out the following points:

(1) The method of preparing the fatty acids for the test is immaterial, and the analyst should be allowed to use the method which seems most convenient to him. There is some danger from fire in alcoholic saponification, but this method is quicker and there is less likelihood of incomplete saponification, though, as Mory has shown, this question is not a serious one. A number of chemists have used methyl alcohol and find it equally satisfactory and much cheaper. The alcohol should be completely removed where the alcoholic method of saponification is used. The scheme given in the Dalican method effects this removal completely.

(2) The fatty acids should be dry. It seems to the referee that a 'careful study of the results of this year' will prove that the method outlined in the Dalican scheme, i. e., filtering and drying twenty minutes at $100^{\circ} \mathrm{C}$., is sufficient and convenient, but does not change the titer.

(3) The method of stirring is the chief factor in the difference in titer, and extraordinary care should be taken by the operator to follow exactly the method prescribed in order that comparable results may be obtained.

(4) The Wolfbauer method of stirring gives higher results, especially on fats of a low titer; it gives more uniform results where there is a variation in temperature; it is the more scientific, and gives more nearly the true titer.

(5) There should be a standard thermometer for titer tests, so that all thermometers used for this purpose would have the same size bulb, the same length of stem, and be made of the same kind of glass, and thus a stem correction could be accurately applied, or else the thermometers should be standardized under the conditions under which they are used. The latter would seem to be the more satisfactory plan.

\section{PROPOSED METHOD.}

The associate referee offers the following tentative method for criticism and discussion, hoping that there will be a full expression of opinion:

Weigh 75 grams of fat into a metal dish and saponify by using $60 \mathrm{cc}$ of 30 per cent sodium hydrate $\left(36^{\circ}\right.$ Baumé caustic soda) and $75 \mathrm{cc}$ of 95 per cent by volume alcohol, or 120 cc of water. Boil down to dryness, with constant stirring, to prevent scorching. This should be done over a very low flame or over an iron or asbestos 
plate. Dissolve the dry soap in a liter of boiling water, and if alcohol has been used boil for forty minutes in order to remove it, adding sufficient water to replace that lost in boiling. Add $100 \mathrm{cc}$ of 30 per cent sulphuric acid ( $25^{\circ}$ Baumé sulphuric acid) to free the fatty acids, and boil until they form a clear, transparent layer. Collect the fatty acids in a small beaker and place on the steam bath until the water has settled, then decant them into a dry beaker, filter, using a hot-water funnel, and dry twenty minutes at $100^{\circ} \mathrm{C}$. When dried, cool the fatty acids to $15^{\circ} \mathrm{C}$. or $20^{\circ} \mathrm{C}$. above the expected titer and transfer to the titer tube, which is $25 \mathrm{~mm}$ in diameter and $100 \mathrm{~mm}$ in length (1 by 4 inches) and made of glass about $1 \mathrm{~mm}$ in thickness. This is placed in a 16-ounce, salt-mouth bottle of clear glass, about $70 \mathrm{~mm}$ in diameter and $150 \mathrm{~mm}$ high ( 24 by 6 inches), fitted with a cork, which is perforated so as to hold the tube rigidly when in position. The thermometer, graduated to $0.1^{\circ}$ C., is suspended so that it can be used as a stirrer, and the mass is stirred slowly until the mercury remains stationary for thirty seconds. The thermometer is then allowed to hang quietly, with the bulb in the center of the mass, and the rise of the mercury observed. The highest point to which it rises is taken as the titer of the fatty acids.

The fatty acids are tested for complete saponification as follows:

Three cc of the fatty acids are placed in a test tube and $15 \mathrm{cc}$ of alcohol (95 per cent by volume) added. The mixture is brought to a boil and an equal volume of ammonia (0.96 sp. gr.) added. A clear solution should result, turbidity indicating unsaponified fat. The room temperature must be reported.

The referee had a thermometer made which removes some of the difficulties. It is graduated in one-tenth degrees from $25^{\circ} \mathrm{C}$. to $60^{\circ} \mathrm{C}$., and has a bulb which allows the temperature to rise much higher without injury to the thermometer. This instrument can always be immersed in the fat to a definite point, and thus the error due to the rising of the mercury column above the liquid will always be the same.

L. M. Tolman, Associate Referee on Fats and Oils.

Recommended for publication.

H. W. WILEY, Chief of Bureau and Secretary A. O. A. C.

Publication authorized. JAMES WILSON, Secretary.

Washington, D. C., January 3, 1905. 
ALL BOOKS ARE SUBJECT TO RECALL RENEW BOOKS BY CALLING 642-3405

\section{DUE AS STAMPED BELOW}

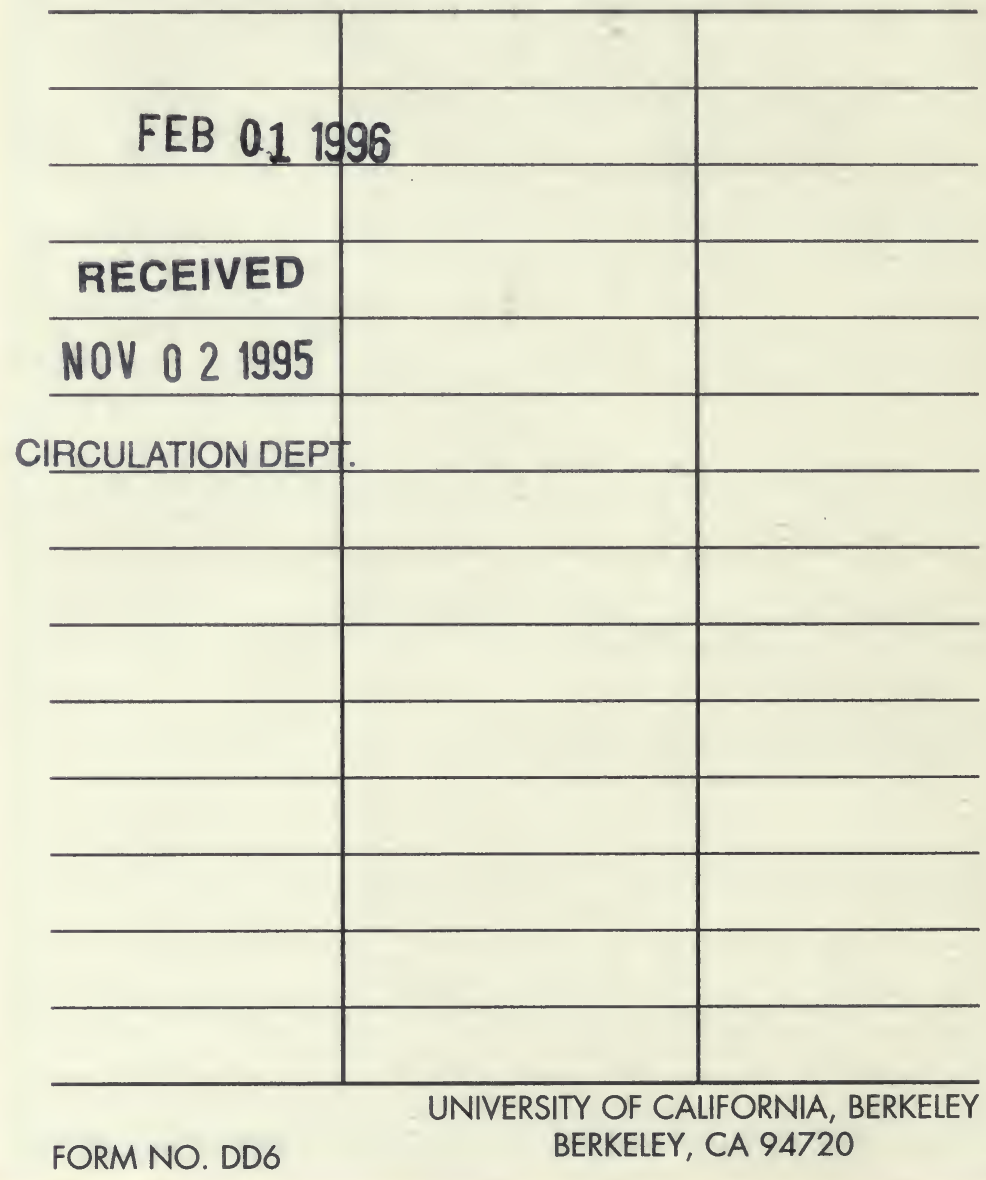




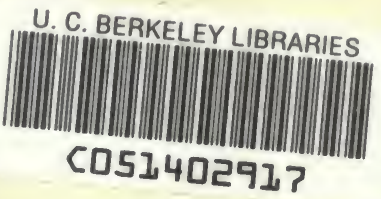




\section{DAY USE}

RETURN TO DESK FROM WHICH BORROWED

\section{LOAN DEPT.}

This book is due on the last date stamped below, or on the date to which renewed.

Renewed books are subject to immediate recall.

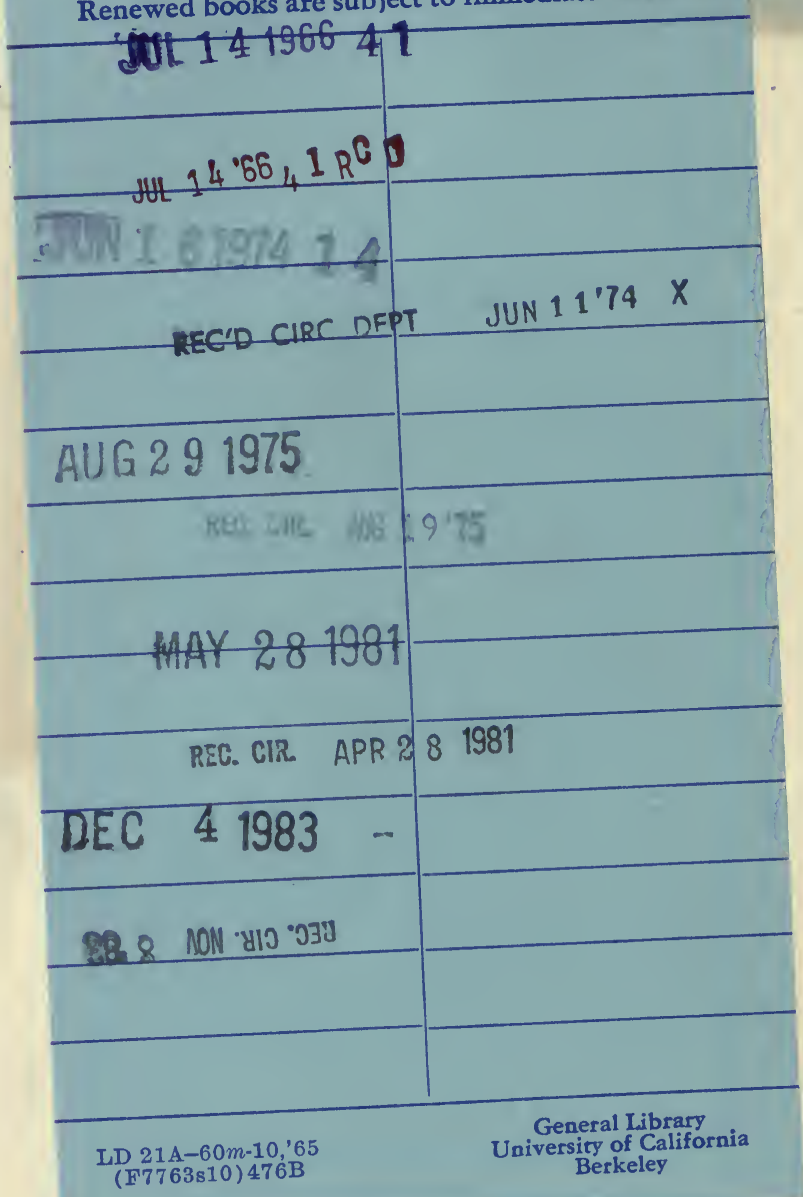




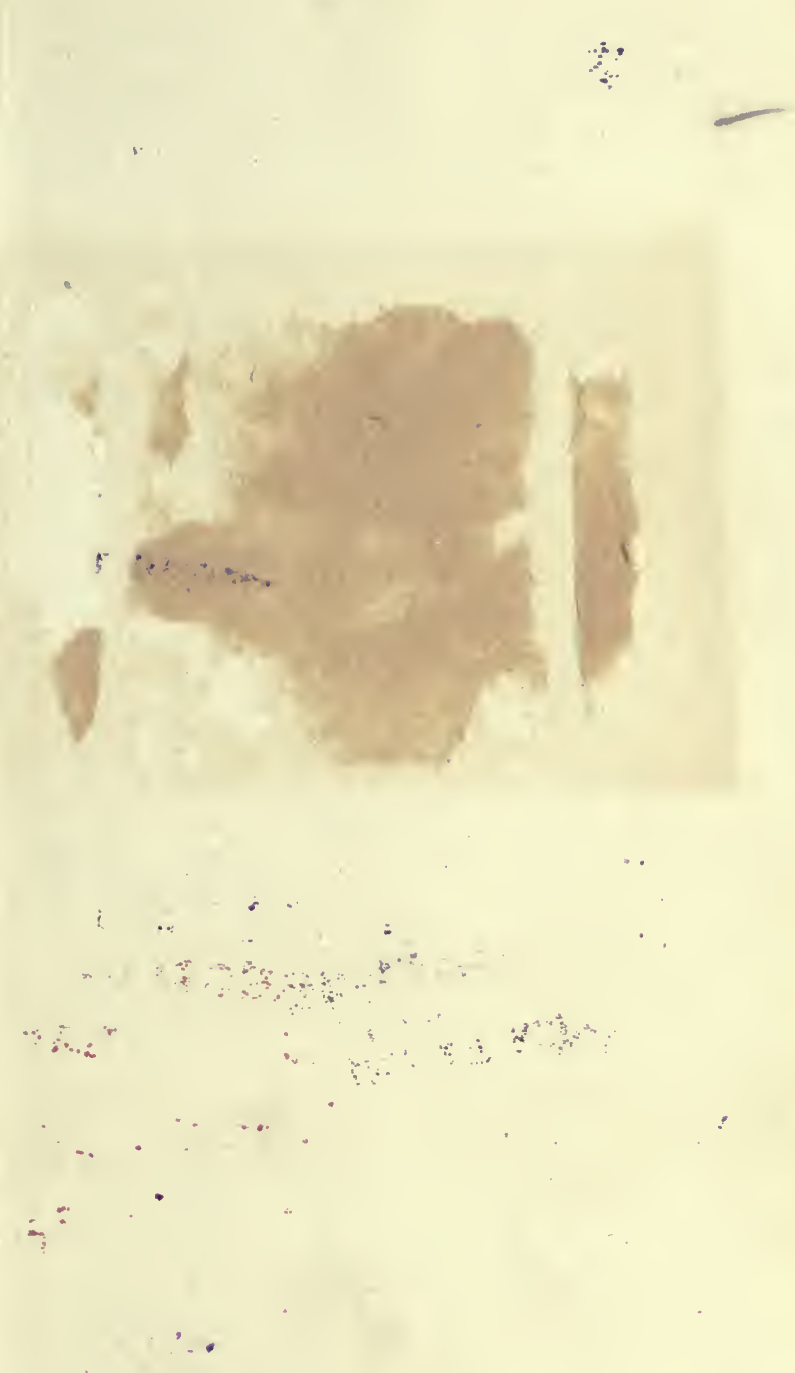


